\title{
Urine Influences Growth and Virulence Gene Expressions in Uropathogenic $E$. coli: A Comparison with Nutrient Limited Medium
}

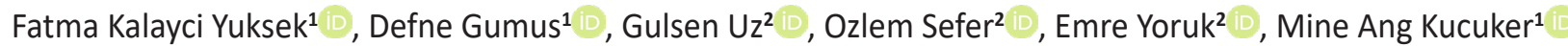 \\ ${ }^{1}$ Istanbul Yeni Yüzyıl University, Faculty of Medicine, Department of Medical Microbiology, Istanbul, Turkey \\ ${ }^{2}$ Istanbul Yeni Yüzyıl University, Faculty of Arts and Sciences, Department of Molecular Biology and Genetics, Istanbul, Turkey \\ Correspondence Author: Fatma Kalayci Yuksek \\ E-mail: fatma.kalayci@yeniyuzyil.edu.tr
}

Received: $07.02 .2020 \quad$ Accepted: 21.04.2021

\begin{abstract}
Objective: The interactions between environmental factors and microbial biological processes are well known. Urine provides host conditions probably affecting bacterial growth and gene expressions. The aim of this study was to detect the modulations of growth and gene expressions [sfa/foc, cnf1, usp and aer] of Uropathogenic E.coli (UPEC) strains in urine by comparing the results with serum supplemented standard American Petroleum Institute (SAPI) medium which is defined as host-like medium.

Methods: UPEC strains $\mathrm{C} 7$ and $\mathrm{C} 149$ were incubated at $37^{\circ} \mathrm{C}$ and growth alterations were detected by measuring the changes in the absorbance at $600 \mathrm{~nm}$ in four-, six - and 24 hours. Gene expression levels were analyzed by quantitative polymerase chain reaction (qPCR). Statistical analysis of fold changes in gene expression values and growths were calculated using one-way ANOVA unpaired t-test and Tukey's post hoc test, respectively.
\end{abstract}

Results: The increase of bacterial growth in urine was found to be statistically significant $(p<0.0001)$. The alterations of $a e r$ and $s f a / f o c$ expression levels were statistically significant ( $p<0.001)$; whereas the expression levels of $\operatorname{cnf1}$ and usp genes were not altered $(p>0.05)$.

Conclusion: According to our results, urine as an environment in vivo affected both the growth and gene expression in UPEC.

Keywords: Urine, Virulence, Growth, Gene Expression, UPEC

\section{INTRODUCTION}

It is well known that microorganisms and their hosts, including human, have co-existed for million years. The interactions between host and microorganisms during an infection were determined by microbial virulence factors, host's immune system and chemicals produced or present in vivo (1-4). On the other hand, the environment of microbe in vivo influences bacterial pathogenicity by affecting growth and virulence mechanisms. Today, behaviors of microorganisms in vivo dominate research and writing $(5,6)$.

Microorganisms encounter with various host derived environmental determinants either present or produced in vivo such as hormones, vitamins, bile salts, sugars, antibiotics, ions, pH etc. (7-12). Urine includes such kind of various host derived determinants and, as an environment of bacteria, alters bacterial growth and gene expressions in different ways (13-22).

The purpose of the present study was to examine whether urine influences the growth and gene expressions [ $\mathrm{sfa} / \mathrm{foc}$ (encodes fimbrial adhesions SF1C), cnf 1 (encodes cytotoxic necrotizing factor 1), usp (encodes a uropathogenic-specific protein) and aer (encodes aerobactin)] of Uropathogenic Escherichia coli (UPEC) which are the most common agents of urinary tract infections (UTIs). For this purpose we compared the growth and gene expression of UPEC in urine and in serum-supplemented standard American Petroleum Institute (SAPI) medium. This medium provides a nutrient limited condition and imitates in vivo (23-25).

\section{METHODS}

\subsection{Strains}

In the present study two different UPECs (E. coli C7 strain carrying $s f a / f o c$, cnf1 and usp genes and E. coli C149 strain carrying aer gene) were used which were kindly provided 
by Prof. Dr. Shingo Yamamoto (Hyogo College of Medicine, Japan). Bacteria were kept at $-80{ }^{\circ} \mathrm{C}$ for all analysis.

\subsection{Media}

Healthy male urine and standard American Petroleum Institute (SAPI) medium supplemented with $30 \%(\mathrm{v} / \mathrm{v})$ adult bovine serum (serum-SAPI) were used as growth media in this study. Healthy male urine was used after sterilized by filtration. Serum-SAPI was defined as a nutrient-limited medium which mimics in vivo growth conditions $(23,24)$. The serum-SAPI medium was prepared as previously described in studies $(23,25,26)$. Briefly, the medium contains 6.25 $\mathrm{mM} / \mathrm{L}$ ammonium nitrate, $1.84 \mathrm{mM} / \mathrm{L}$ monobasic potassium phosphate, $2.77 \mathrm{mM} / \mathrm{L}$ dextrose, $3.35 \mathrm{mM} / \mathrm{L}$ potassium chloride, and $1.01 \mathrm{mM} / \mathrm{L}$ magnesium sulphate and $\mathrm{pH}$ adjusted as 7.5 .

\subsection{Comparison of Growth in Urine and SAPI}

Overnight cultures of E. coli C7 and C149 were prepared in SAPI medium and these were five-fold diluted and inoculated into SAPI medium and urine. Bacteria were incubated at $37^{\circ} \mathrm{C}$. Growth alterations were detected by measuring the changes in absorbance at $600 \mathrm{~nm}$ in four-, six - and 24-h periods. The samples were tested in duplicate and each experiment was performed twice.

\subsection{Comparison of Gene Expressions in Urine and SAPI}

\section{Total RNA isolation and CDNA synthesis}

Bacteria were grown in SAPI medium and human urine for 16-24 h at $37^{\circ} \mathrm{C}$. Total RNAs were extracted from 24-h-fresh cultures by using Tripure reagent (Roche, Switzerland) according to manufacturer's instructions. Horizontal electrophoresis gel analysis and spectrophotometer measurement used to analyze of isolated RNAs quantitatively and qualitatively. We detected the concentration and purity of total RNAs using a NanoDrop 2000 spectrophotometer Thermo Scientific (Waltham-USA). Total RNAs with a ratio (A260/A280) > 1.8 were used for quantitative PCR (qPCR) analysis. Total RNAs were also screened by $1 \%$ horizontal gel electrophoresis. High quality and amounts of RNAs were converted to cDNA for qPCR assays. Reverse transcription was carried out using commercial CDNA conversion kit (Takara, Japan) according to the manufacturer's instructions. The thermal cycle conditions were as follows: $20 \mathrm{~min}$ at $37^{\circ} \mathrm{C}$, 5 min at $85^{\circ} \mathrm{C}$ and cooling at $4^{\circ} \mathrm{C}$. After reverse transcription step, 1:5 diluted cDNAs were used in gene expression analysis.

\section{Quantitative polymerase chain reaction (qPCR) analysis}

Quantitative PCR reactions were carried out using SYBR Green I fluorophore dye (Takara, Japan) according to the instructions of the manufacturer. 16S rRNA gene was used as housekeeping gene. We detected the expression levels of $s f a / f o c$ (S and F1C fimbria), usp (uropathogenic-specific protein) and cnf1 (cytotoxic necrotizing factor) for C7 strain and aer gene (aerobactin) for C149 strain in the presence of urine and SAPI medium. Quantitative PCRs were carried out in a reaction volume of $16 \mu \mathrm{L}$ including $1 X$ SYBR Green I, 0. 5 pmol of primers (Table 1 ) and $2 \mu \mathrm{L}$ of cDNA equivalent to 50 ng total RNA. Quantitative PCR conditions were shown in Table 2 for all genes. Sensitivity and accuracy of the protocol were tested at different levels by performing melting curve analysis, using $16 \mathrm{~S}$ rRNA as control. Ct values were obtained and calculated using Quant Studio 5.0 software (Applied Biosystem, USA). Relative quantification strategy was used in obtaining fold changes in gene expression using $2^{-\Delta \Delta C T}$ formula. The experiments were conducted in quadruple and the results were presented as fold change for each gene.

Table 1. Primers used in the gene expression

\begin{tabular}{|l|l|l|l|} 
Gene & Nucleotide sequence $\left(\mathbf{5}^{\prime} \mathbf{- 3}^{\prime}\right)$ & $\begin{array}{l}\text { Band } \\
\text { size } \\
\text { (bp) }\end{array}$ & References \\
\hline $\begin{array}{l}\text { 16S } \\
\text { rRNA }\end{array}$ & $\begin{array}{l}\text { F: CCA GGA TTT GAT YMT GGC } \\
\text { R: GAA GGA GGT GWT CCA DCC }\end{array}$ & 532 & 27,28 \\
\hline sfa/foc & $\begin{array}{l}\text { F: CTC CGG AGA ACT GGG TGC ATC TTA C } \\
\text { R: CGG AGG AGT AAT TAC AAA CCT GGC A }\end{array}$ & 410 & 29,30 \\
\hline usp & $\begin{array}{l}\text { F: CGG CTC TTA CAT CGG TGC GTT G } \\
\text { R: GAC ATA TCC AGC CAG CGA GTT C }\end{array}$ & 615 & 29 \\
\hline cnf1 & $\begin{array}{l}\text { F: AAG ATG GAG TTT CCT ATG CAG GAG } \\
\text { R: CAT TCA GAG TCC TGC CCT CAT TAT T }\end{array}$ & 498 & 29,30 \\
\hline aer & $\begin{array}{l}\text { F: TAC CGG ATT GTC ATA TGC AGA CCG T } \\
\text { R: AAT ATC TTC CTC CAG TCC GGA GAA G }\end{array}$ & 602 & 29,30 \\
\hline & \multicolumn{2}{|l}{} & \\
\hline
\end{tabular}

Table 2. Quantitative polymerase chain reaction ( $q P C R$ ) conditions

\begin{tabular}{|c|c|c|}
\hline Step & Time & Temperature \\
\hline Pre-denaturation & 2 minute & $95^{\circ} \mathrm{C}$ \\
\hline \multicolumn{3}{|c|}{ Number of cycling: 45} \\
\hline Denaturation & 10 second & $95^{\circ} \mathrm{C}$ \\
\hline Annealing & 15 second & $58^{\circ} \mathrm{C}$ \\
\hline Extension & 20 second & $72^{\circ} \mathrm{C}$ \\
\hline Cooling & 30 second & $40^{\circ} \mathrm{C}$ \\
\hline
\end{tabular}

\subsection{Statistical Analysis}

Statistical analysis of fold changes in gene expression values were calculated using one way ANOVA unpaired t-test and growths were calculated using one-way ANOVA Tukey's post hoc test. All measurements were compared to control. All results were presented as mean \pm standard deviation (SD). The multiple comparisons were made at a level of $p<0.05$.

\section{RESULTS}

\subsection{Comparison of Growth in Urine and SAPI}

In order to detect the effects of human urine on growth of UPECs, the absorbance values were compared to SAPI (control medium). The growth of UPEC in urine was enhanced which was found to be statistically significant $(p<0.001)$ in the $4^{\text {th }}, 6^{\text {th }}$ and $24^{\text {th }}$ hours (Figure 1 , Figure 2 and Figure 3 ). 


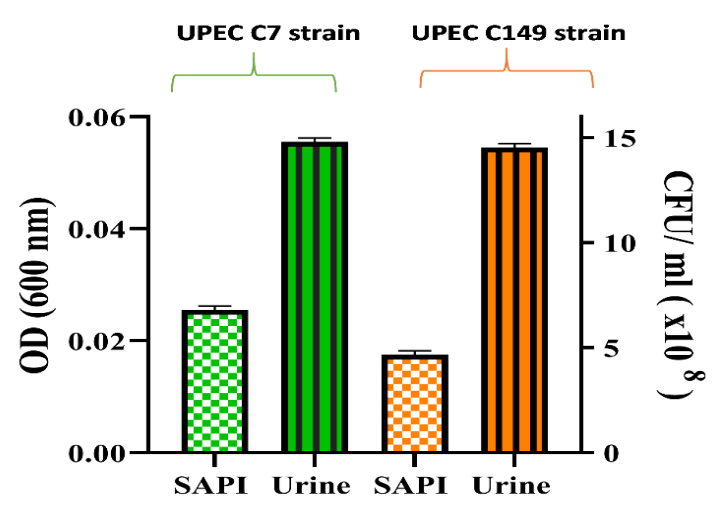

Figure 1. Comparison of UPECS (C7 and C149 strains) growth in urine and SAPI medium in the 4th hour. The alterations were determined by comparing with control (SAPI medium). The growth alterations of bacteria in urine and SAPI were examined using one-way ANOVA followed by Tukey's post hoc test. The difference between the growth of UPECS in urine and SAPI medium were found to be statistically significant $(p<0.0001)$.

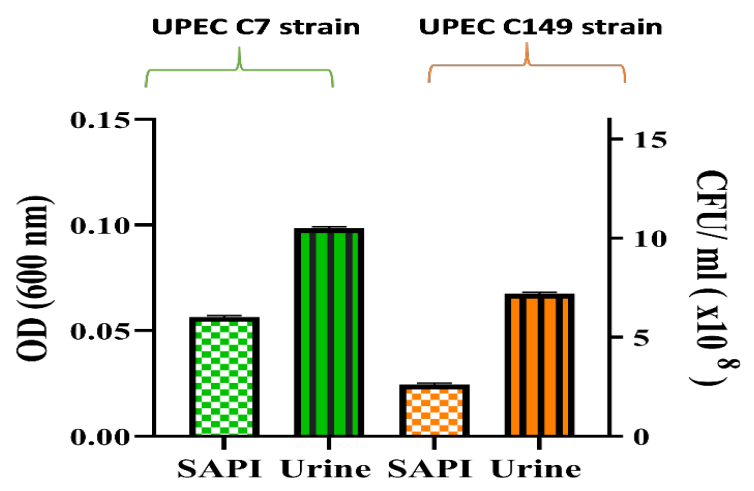

Figure 2. Comparison of UPECS (C7 and C149 strains) growth in urine and SAPI medium in the 6th hour. The alterations were determined by comparing with control (SAPI medium). The growth alterations of bacteria in urine and SAPI were examined using one-way ANOVA followed by Tukey's post hoc test. The difference between the growth of UPECS in urine and SAPI medium were found to be statistically significant $(p<0.0001)$.

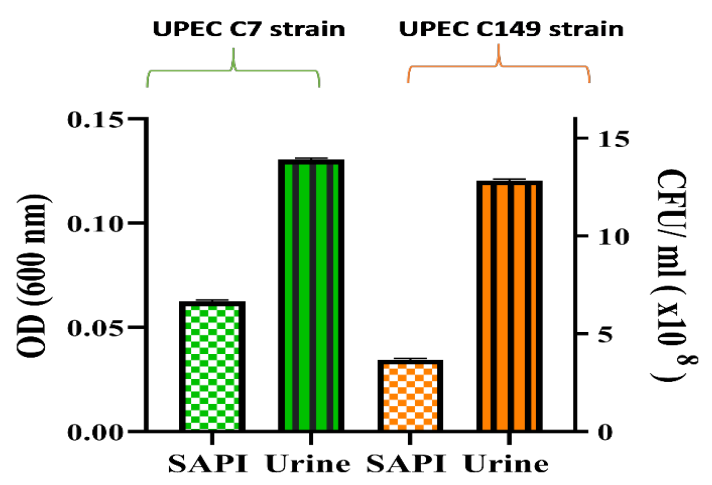

Figure 3. Comparison of UPECS (C7 and C149 strains) growth in urine and SAPI medium in the 24th hour. The alterations were determined by comparing with control (SAPI medium). The growth alterations of bacteria in urine and SAPI were examined using one-way ANOVA followed by Tukey's post hoc test. The difference between the growth of UPECS in urine and SAPI medium were found to be statistically significant $(p<0.0001)$.

\subsection{Comparison of Gene Expressions in Urine and SAPI}

The down regulation of aer gene was found to be statistically significant in urine $(p<0.01)$. The expression of $s f a / f o c$ gene was increased in urine $(p<0.01)$. However, no statistically significant difference was found in the expression levels of cnf 1 and usp ( $p>0.05$ ) (Figure 4). Ct values in all genes ranged from 6.60 to 26.64 .

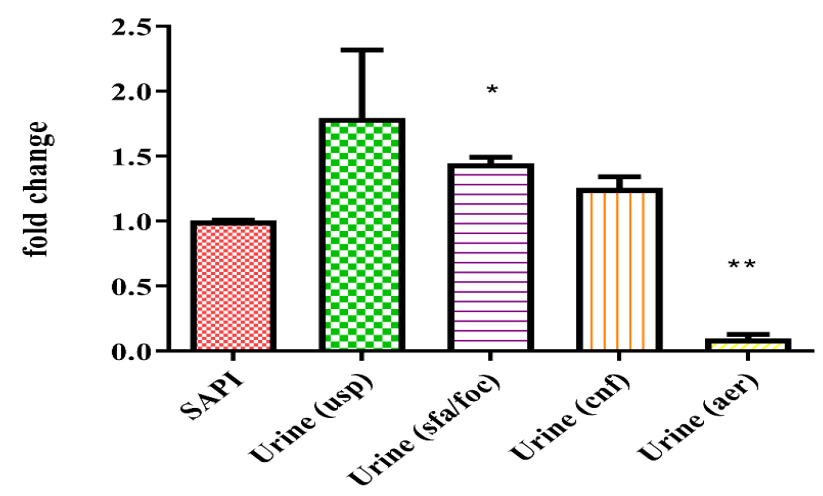

Figure 4. Comparison of gene expressions in urine and SAPI. The alterations were determined by comparing with control (SAPI medium). Statistical analysis was calculated using one-way ANOVA unpaired t test. *,**: Significant at $p<0.01$ level and $p<0.001$ level values, respectively.

\section{DISCUSSION}

Globally a large number of people suffer from UTIs which are mostly caused by UPEC strains. UPECs have different virulence factors as compared to other E.coli strains. Some of these virulence factors are fimbrial adhesins encoded by $s f a / f o c$ genes, a siderophore for iron uptake encoded by aer gene, cytotoxic necrotizing factor 1 encoded by cnf1 gene, and uropathogenic-specific protein which has endonuclease activity encoded by usp gene $(31,32)$. The expression of UPEC virulence genes may be affected by environmental conditions determined by host factors. It is well known that during infectious process, bacteria sense in vivo environmental changes and adapt to them.

As it was stated above, not only physiological conditions such as $\mathrm{pH}$, temperature, but also many host determinants either present or produced in vivo regulate the growth and gene expression of microorganism during infection (3 $6,14,18,19,22,33-35)$. It was suggested by some authors that, urine contains high concentrations of various metabolites which induce the growth of bacteria, whereas the others define the urine as a nutrient limited medium (with regard to amounts of iron, amino acids and nucleotides) $(14,16,17,20,36-38)$.

There are many studies aimed on the effect of human urine on bacterial growth and gene expression in different bacteria. It was shown that $\mathrm{pH}$, the amount of glucose, iron, osmolality, ammonium, organic acids, creatinine and urea of urine are important factors affecting growth of bacteria (16-22, 39-41). 
Our study was designed in a different way to examine the influence of human urine on growth and virulence gene expression in UPEC (urine compared to serum SAPI medium).

The bacterial growth is the first step in the infection process which is necessary for avoidance of immune response and infection. Roos et al. have shown that the in vitro growth ability of E.coli in urine was strain depended. E. coli 83972 strain was grown well in urine depending on the individual batch of urine used, but $E$. coli K-12 reference strain MG1655 could not grow in urine. They also reported that E.coli 83972 strain was grown better than the K12 strain both in Luria Bertani (LB) broth, a nutritionally rich medium and human urine. They also showed that strain 83272 was grown better than some clinical isolated E.coli strains (536, CFT073, NU14, and 1177) in urine which were isolated from patients with UTIs (39). Alteri and Mobley have indicated that the in vitro growth rates in urine of enteropathogenic and commensal E. coli strains was generally similar to that of UPEC's (40). In contrast to these results, Aubron et al. suggested that the in vitro growth of different $E$. coli strains (8 UPEC, 1 Enterohemorrhagic E. coli, 9 asymptomatic bacteriuria causing strains and 3 commensal strains) was significantly less than in LB medium compared to growth levels in urine. They also found that the growth ability of asymptomatic bacteriuria strains in the urine was not better than of UPEC and commensal E.coli strains (41).

In the present study we found that urine induced the growth of UPEC significantly ( $p<0.001$ ) when compared to serumsupplemented SAPI medium. Our results are consistent with previous studies; serum-SAPI medium has reduced the growth of UPEC when compared to Tryptic Soy Broth, Dulbecco's Modified Eagle's Medium etc. in the $4^{\text {th }}, 6^{\text {th }}$ or $24^{\text {th }}$ hours $(27,28,42)$. Urine seems a good growth medium for $E$. coli due to contain several inorganic and organic compounds and the growth of UPEC was provided effectively by fresh urine for this study.

The effects of urine on microbial virulence related gene expressions were shown in many in-vivo and in-vitro studies $(18,19,22,33,34,40,43,44)$. Greene et al. concluded that when $E$. coli grown in urine, fim expression was found to be prevented. They also suggested that urine has inhibitory effects on FimH function (18). In a study of Hancock and Klemm the expression levels of 815 genes were examined in urine by comparing planktonic and biofilm forming strains and they reported that the expression levels of pap and foc genes were found to be not altered but fyuA gene (encoding siderophore receptor) expression was upregulated (19). Russo et al. found that expression level of $i r o N_{\text {E.coli }}$ (encoding siderophore receptor) was increased in urine (22). King et al. found K1 capsule genes of a UPEC strain were downregulated in urine (34). Roos et al. showed that expression levels of iron-uptake, transport system and adhesionassociated genes, pap, $s f a / f o c$ genes, were upregulated when E.coli strain grown in urine (39). Snyder et al. reported the expression levels of E.coli CFT073 genes both of in vivo and in vitro (urine compared to LB) conditions. They reported that many of the most highly expressed genes in vivo conditions were also among the most highly expressed in urine. Some of the upregulated genes were reported as related with iron acquisition systems, capsular compositions, microcin secretion genes (43). In consistent with Snyder et al., Hagan et al. suggested that $E$. coli gene expressions were generally similar in urine provided from women with UTIs and infected mouse. The most significantly differences in expression levels were reported for genes encoding adhesins (44).

In our study, expression of aer gene which is responsible for iron uptake in UPEC was found to be down-regulated; this result is inconsistent with other studies. The upregulation of $s f a / f o c$ gene related to adhesion of the pathogen to the urinary tract; this result was consistent with the previous studies $(39,43)$. In line with all these results, we may suggest that these discrepancies related to be depend on strain, compared to medium/conditions.

\section{CONCLUSION}

In many studies mentioned above, the comparison of growth, expression levels of genes encoding virulence factors were investigated by using urine and standard bacteriological culture media such as Luria-Bertani, Tryptic soy broth etc. However, in our study nutrient limited SAPI medium was used which mimics in vivo environment. For detection of behaviors of pathogens in vitro, studies are needed to prepare proper alternatives for culture media to provide mimicking in vivo conditions.

\section{REFERENCES}

[1] Freestone P. Communication between bacteria and their hosts. Scientifica (Cairo) 2013; 2013:361073.

[2] Bakholdina SI, Sanina NM, Krasikova IN, Popova OB, Soloveva TF. The impact of abiotic factors (temperature and glucose) on physicochemical properties of lipids from Yersinia pseudotuberculosis. Biochimie 2004; 86 (12):875-881.

[3] Lyte M. Bacteria and hormones: Why the science of microbial endocrinology matters to disease and well-being. Heidt PJ, Midtvedt T, Volker R \& Versalovic J, editors. Bacterial species as partners and pathogens. Germany: Old Herborn University Seminar Monograph; 2012.p.17-29.

[4] Hughes DT, Sperandio V. Inter-kingdom signaling: communication between bacteria and their hosts. Nat Rev Microbiol 2008; 6(2):111-120.

[5] Lyte M, Freestone PP. Microbial Endocrinology. Interkingdom Signaling in Infectious Disease and Health. New York: Springer; 2010.

[6] Kendall MM, Sperandio V. What a dinner party! Mechanisms and functions of interkingdom signaling in host-pathogen associations. mBio 2016;7(2):e01748-15.

[7] Hamner S, McInnerney K, Williamson K, Franklin MJ, Ford TE. Bile salts affect expression of Escherichia coli 0157: H7 genes for virulence and iron acquisition, and promote growth under iron limiting conditions. PLoS One 2013;8(9):e74647. 
[8] Hirakawa H, Inazumi Y, Masaki T, Hirata T, Yamaguchi A. Indole induces the expression of multidrug exporter genes in Escherichia coli. Mol Microbiol 2005;55(4):1113-26.

[9] Klosowska K, Plotkin BJ. Human insulin modulation of Escherichia coli adherence and chemotaxis. Am J Infect Dis 2006;(2)4:197-200.

[10] Kurakado S, Kurogane R, Sugita T. 17ß-Estradiol inhibits estrogen binding protein-mediated hypha formation in Candida albicans. Microb Pathog 2017;109:151-155.

[11] Delcenserie V, LaPointe G, Charaslertrangsi T, Rabalski A, Griffiths MW. Glucose decreases virulence gene expression of Escherichia coli 0157: H7. J Food Prot 2012; 75(4):748-52.

[12] Gönüllü N, Küçükbasmacı Ö, Büyükbaba-Boral Ö, Anğ-Küçüker $M$. The influence of glucose added urine on the in vitro antimicrobial activity of various antibiotics. Indian J Med Res 2008;128(5):663-5.

[13] Stamey TA, Mihara G. Observations on the growth of urethral and vaginal bacteria in sterile urine. J Urol 1980;124(4): 461463.

[14] Hull RA, Hull SI. Nutritional requirements for growth of uropathogenic Escherichia coli in human urine. Infect Immun 1997;65(5): 1960-1961.

[15] Gordon DM, Riley MA. A theoretical and experimental analysis of bacterial growth in the bladder. Mol Microbiol 1992;6(4): 555-562.

[16] Vejborg RM, de Evgrafov MR, Phan MD, Totsika M, Schembri MA, Hancock V. Identification of genes important for growth of asymptomatic bacteriuria Escherichia coli in urine. Infect Immun 2012;80(9):3179-3188.

[17] Mann R, Mediati DG, Duggin IG, Harry EJ, Bottomley AL. Metabolic adaptations of uropathogenic $E$. coli in the urinary tract. Front Cell Infect Microbiol 2017;7: 241.

[18] Greene SE, Hibbing ME, Janetka J, Chen SL, Hultgren SJ. Human urine decreases function and expression of type 1 pili in uropathogenic Escherichia coli. mBio 2015; 6(4):e00820-15.

[19] Hancock V, Klemm P. Global gene expression profiling of asymptomatic bacteriuria Escherichia coli during biofilm growth in human urine. Infect Immun 2007;75(2);966-976.

[20] Schwan WR, Lee JL, Lenard FA, Matthews BT, Beck MT. Osmolarity and $\mathrm{pH}$ growth conditions regulate fim gene transcription and type 1 pilus expression in uropathogenic Escherichia coli. Infect Immun 2002;70(3):1391-1402.

[21] Thornton LA, Burchell RK, Burton SE, Lopez-Villalobos N, Pereira D, MacEwan I, Velathanthiri N. The effect of urine concentration and $\mathrm{pH}$ on the growth of Escherichia coli in canine urine in vitro. J Vet Intern Med 2018;32(2):752-756.

[22] Russo TA, Carlino UB, Mong A, Jodush ST. Identification of genes in an extraintestinal isolate of Escherichia coli with increased expression after exposure to human urine. Infect Immun 1999;67(10): 5306-5314.

[23] Freestone PP, Haigh RD, Williams PH, Lyte M. Stimulation of bacterial growth by heat-stable, norepinephrine-induced autoinducers. FEMS Microbiol Lett 1999;172(1):53-60.

[24] Freestone PP, Sandrini SM, Haigh RD, Lyte M. Microbial endocrinology: how stress influences susceptibility to infection. Trends Microbiol 2008;16(2): 55-64.

[25] Lyte M, Ernst S. Catecholamine induced growth of gram negative bacteria. Life Sci 1992; 50:203-12.

[26] Lyte M, Freestone PP, Neal CP, Olson BA, Haigh RD, Bayston $\mathrm{R}$, Williams $\mathrm{PH}$. Stimulation of Staphylococcus epidermidis growth and biofilm formation by catecholamine inotropes. Lancet 2003;361(9352): 130-135.

[27] Gumus D, Yoruk E, Kalayci-Yuksek F, Uz G, Topal-Sarikaya A, Ang-Kucuker M. The effects of insulin and glucose on different characteristics of a UPEC: Alterations in growth rate and expression levels of some virulence genes. Clin Lab 2017;63(10): 1589-97.

[28] Gümüş D, Yüksek FK, Sefer Ö, Yörük E, Uz G, Küçüker MA. The roles of hormones in the modulation of growth and virulence genes' expressions in UPEC strains. Microb Pathog 2019;132:319-324.

[29] Takahashi A, Kanamaru S, Kurazono H, Kunishima Y, Tsukamoto T, Ogawa O, Yamamoto S. Escherichia coli isolates associated with uncomplicated and complicated cystitis and asymptomatic bacteriuria possess similar phylogenies, virulence genes, and O-serogroup profiles. J Clin Microbiol 2006;44(12):4589-4592.

[30] Yamamoto S, Terai A, Yuri K, Kurazono H, Takeda Y, Yoshida O. Detection of urovirulence factors in Escherichia coli by multiplex polymerase chain reaction. FEMS Immunol Med Microbiol 1995;12:85-90.

[31] Miyazaki J, Ba-Thein W, Kumao T, Obata Yasuoka M, Akaza H, Hayshi H. Type 1, P and S fimbriae, and afimbrial adhesin I are not essential for uropathogenic Escherichia coli to adhere to and invade bladder epithelial cells. FEMS Immunol Med Microbiol 2002;25:23-6.

[32] Yamamoto S. Molecular epidemiology of Escherichia coli. J Infect Chemother 2007; 13:68-73.

[33] Andersen-Civil AIS, Ahmed S, Guerra PR, Andersen TE, Hounmanou YMG, Olsen JE, Herrero-Fresno A. The impact of inactivation of the purine biosynthesis genes, purN and purT, on growth and virulence in uropathogenic $E$. coli. Mol Biol Rep 2018;45(6):2707-2716.

[34] King JE, Owaif HAA, Jia J, Roberts IS. Phenotypic heterogeneity in expression of the $\mathrm{K} 1$ polysaccharide capsule of uropathogenic Escherichia coli and downregulation of the capsule genes during growth in urine. Infect Immun 2015;83(7): 2605-2613.

[35] Schwan WR, Beck MT, Hung CS, Hultgren SJ. Differential regulation of Escherichia coli fim genes following binding to mannose receptors. J Pathog 2018;22: 2897581.

[36] Altman PL. Physical properties and chemical composition of urine: mammals. Dittmer DL, editor. Part 1: Man. In Blood and Other Body Fluids. Washington, DC: Federation of American Societies for Experimental Biology; 1961.p.363-369.

[37] Asscher AW, Sussman M \& Weisser R. Bacterial growth in human urine. O'Grady F, Brumfitt W, editors. Urinary Tract Infection. London: Oxford University Press; 1968.p.3-13.

[38] Asscher AW, Sussman M, Waters WE, Davis RH, Chick S. Urine as a medium for bacterial growth. Lancet 1966; 2:1037.

[39] Roos V, Ulett GC, Schembri MA, Klemm P. The asymptomatic bacteriuria Escherichia coli strain 83972 outcompetes uropathogenic $E$. coli strains in human urine. Infect Immun 2006;74(1): 615-624.

[40] Alteri CJ, Mobley HL. Quantitative profile of the uropathogenic Escherichia coli outer membrane proteome during growth in human urine. Infect Immun 2007;75(6):2679-2688.

[41] Aubron C, Glodt J, Matar C, Huet O, Borderie D, Dobrindt $U$, Bouvet $O$. Variation in endogenous oxidative stress in Escherichia coli natural isolates during growth in urine. BMC Microbiol 2012;12(1): 120.

[42] Gümüş D, Kalaycı Yüksek F, Gündoğan Gi, Anğ Küçüker M. The alterations on growth of a Uropathogenic E. coli with the 
effects of both different hormones and cell lines. Kocaeli Med J 2020; 9(2): 68-76.

[43] Snyder JA, Haugen BJ, Buckles EL, Lockatell CV, Johnson DE, Donnenberg MS, Mobley HL. Transcriptome of uropathogenic
Escherichia coli during urinary tract infection. Infect Immun 2004;72(11): 6373-6381.

[44] Hagan EC, Lloyd AL, Rasko DA, Faerber GJ, Mobley HL. Escherichia coli global gene expression in urine from women with urinary tract infection. PLoS Pathog 2010; 6(11):e1001187.

How to cite this article: Kalayci Yuksek F, Gumus D, Uz G, Sefer O, Yoruk E, Ang Kucuker M. Urine Influences Growth and Virulence Gene Expressions in Uropathogenic E. Coli: A Comparison With Nutrient Limited Medium. Clin Exp Health Sci 2021; 11: 209-214. DOI :10.33808/ clinexphealthsci.686302 